DOI 10. 18307/2020. 0525

(C) 2020 by Journal of Lake Sciences

\title{
梯级筑坝对黑河水质时空分布特征的影响"
}

\author{
王 昱 ${ }^{1,2 * *}$, 卢世国 ${ }^{1}$, 冯 起 ${ }^{2}$, 刘 蔚 $^{2}$, 刘娟娟 ${ }^{1},{\text { 刘 } \text { 清 }^{3} \text {, 左一锋 }}^{1}$ \\ (1: 兰州理工大学能源与动力工程学院,兰州 730050) \\ (2: 中国科学院西北生态环境资源研究院内陆河流域生态水文重点实验室,兰州 730000) \\ (3: 甘肃省讨赖河流域水资源局,酒泉 735000)
}

\begin{abstract}
摘 要: 为探究梯级大坝建设对河流水质变化规律的影响,将黑河上中游划分为坝上河段、坝下河段及自然河段,于 2017 年 12 月- 2018 年 8 月选取了 24 个主要控制断面进行水质调查, 并采用多元统计的方法对比分析了不同时空尺度上的水 质分布特征. 结果表明: 黑河上中游水质时空变化的主要影响因子为水温 (WT)、pH 值、溶解氧 ( DO)、电导率 ( EC)、总氮 $(\mathrm{TN})$ 、总磷 $(\mathrm{TP})$ 和五日生化需氧量 $\left(\mathrm{BOD}_{5}\right)$. 空间尺度上, $\mathrm{WT} 、 \mathrm{EC} 、 \mathrm{BOD}_{5}$ 、高锰酸盐指数 $\left(\mathrm{COD}_{\mathrm{Mn}}\right) 、 \mathrm{TN}$ 等指标具有显著性 差异, 其中坝上河段受 $\mathrm{BOD}_{5} 、 \mathrm{COD}_{\mathrm{Mn}}$ 影响较大, 自然河段 WT、EC 和 $\mathrm{TN}$ 为关键指标, 而各个因子对坝下河段水质影响较 小. 时间尺度上, $\mathrm{WT} 、 \mathrm{EC} 、 \mathrm{BOD}_{5}$ 、氨氮与季节变化存在明显相关性, 是不同河段水质时间变化的控制因子, 且大多数水质 因子在非汛期变化最明显. 降水、温度、水文条件等季节性影响因素和梯级水库联合运用模式是该区域水质时间差异的 主要原因; 空间差异主要受祁连、张掖地区外源性污染物排放以及筑坝环境下水动力条件改变而产生的沉积滞留效应和 沿程累积效应影响. 研究表明, 外源性污染源依然是导致水质变差的主要因素, 梯级筑坝则是导致水质变差的间接因素. 因此控制该区域人类活动所造成的外源性污染源, 并针对不同种类污染物的季节变化特征实施合理的水库运行方式是 改善水电梯级开发河段水质状况的关键.
\end{abstract}

关键词: 水质;多元统计;时空变化;梯级大坝; 黑河

\section{Effect of cascade dam construction on the spatio-temporal variations of water quality in Heihe River*}

\author{
WANG Yu ${ }^{1,2 * *}$, LU Shiguo $^{1}$, FENG $i^{2}$, LIU Wei $^{2}$, LIU Juanjuan ${ }^{1}$, LIU Kaiqing ${ }^{3}$ \& ZUO Yifeng ${ }^{1}$ \\ (1: School of Energy and Power Engineering, Lanzhou University of Technology, Lanzhou 730050, P.R. China) \\ (2: Key Laboratory of Ecohydrology of Inland River Basin, Northwest Institute of Eco-environment and Resources, Chinese A- \\ cademy of Sciences, Lanzhou 730000 , P.R.China) \\ (3: Taolaihe Basin Water Resourse Authority of Gansu Province, Jiuquan 735000, P.R.China)
}

Abstract: Construction of casade dams in Heihe River had a certain influence on the river water quality. We divided the water into upstream and downstream reaches of dam and natural reaches. To explore the impact of casade dams on the water quality, multivariate statistical methods were used to analyze the spatio-temporal characteristics of water quality based on 24 different sampling sites from december 2017 to august 2018. The results showed that the main impact factors on water quality in Heihe River were water temperature (WT), $\mathrm{pH}$, dissolved oxygen ( DO), electrical conductivity ( EC), total nitrogen ( TN ), total phosphorus ( TP) and biochemical oxygen demand $\left(\mathrm{BOD}_{5}\right)$. WT, EC, $\mathrm{BOD}_{5}$, chemical oxygen demand $\left(\mathrm{COD}_{\mathrm{Mn}}\right)$ and TN varied signnificantly on the spatial scales. The water quality of the upstream reaches of dam were greatly affected by $\mathrm{BOD}_{5}$ and $\mathrm{COD}_{\mathrm{Mn}}$, while WT, EC and TN were the key drivers for the natural reaches and less environmental influence on the downstream water quality. In temporal terms, $\mathrm{WT}, \mathrm{EC}, \mathrm{BOD}_{5}$ and ammonia nitrogen excerted the greatest effects on the water quality, with most of the water quality factors changed obviously in non flood seasons. Factors such as temperature, rainfall, hydrological conditions and the joint operation mode of cascade reservoirs were the main factors affecting the seasonality of water quality in the region. The spatial differences were main-

* 2019-12-04 收稿;2020-02-29 收修改稿.

国家自然科学基金项目 (51669011) 和甘肃省自然科学基金重大项目 (18JR4RA002) 联合资助.

** 通信作者;E-mail:wangyu-mike@163.com. 
ly influenced by the exogenous pollutants discharging in Qilian and Zhangye areas, and the influence of sediment retention and accumulation on the environment of dam construction due to the change of hydrodynamic conditions. The results show that exogenous pollution sources were still the main factors, followed by the cascade dam construction as the indirect factors, for the water quality deterioration. Therefore, controlling the exogenous pollution sources caused by human activities in the region, and implementing a reasonable reservoir operation mode according to the seasonal variation of pollutants were the key to improve the river water quality along with the cascade hydropower development.

Keywords: Water quality; multivariate analysis; spatio-temporal variation; cascade dams; Heihe River

河流水质是流域的一个重要特征, 通过研究水体中物理化学成分的变化, 不仅可以获取地质、气象、水 文等自然因素在河流中形态表征的信息,同时还能体现流域范围内社会经济、人类活动对河流水系作用的 响应 ${ }^{[1]}$. 近年来, 随着流域梯级开发, 原始河流的水力学连通性和纵向联通性发生改变, 在很大程度上重新 配置了上下游河道物质、能量和水流输送的时空分布特征, 进而影响到河流的水文过程、水动力条件、介质 运移机制等水文环境要素, 这些将成为水体富营养效应的叠加因素 ${ }^{[2-3]}$; 另外, 河流水动力条件的变化势必 会影响沉积物粒度的组成和分布 ${ }^{[4]}$, 而河流沉积物作为水体污染物 (如营养盐颗粒) 的重要载体, 其粒度特 性的改变将会制约水体理化物质的迁移转化行为. 因此, 开展水电梯级开发情景下河流水质变化规律研究, 对于流域生态修复和水库调度具有重要意义. 目前, 国内外学者针对水电开发对河流水质变化的影响进行 了大量研究. Dynesius 等 ${ }^{[5]}$ 研究表明, 水库建设将导致河流水动力条件减弱, 阻碍了颗粒态营养要素的迁移 方式, 从而加重了库区水体富营养化趋势; Petts ${ }^{[6]}$ 认为水库水质发生变化的主要影响因素是水库运用方式、 水位、分层、滞留时间、异重流等; 刘丛强等 ${ }^{[7]}$ 分析表明,太阳辐射和热量传输不平衡会导致季节性水体分 层, 主要体现在库区水温结构分层和下泄水温的延迟滞留效应上; 此外, 国内外不少学者 ${ }^{[8-10]}$ 认为梯级水库 运行对水质的影响必然会以某种形式叠加, 产生累积效应. 但上述研究大都集中在长江流域、黄河流域、澜 沧江流域、Seine 河流域等外流河及其支流上,对内陆河流域这样水质脆弱地区的案例性研究并不多见.

黑河作为我国第二大内陆河, 是河西走廊绿洲赖以生存和社会经济可持续发展的重要水资源基地. 近 年来, 黑河上游水电梯级开发极大地破坏了河流连续性, 不仅使库区自身水体理化性质的时空分布发生变 化, 还对下游河道水环境系统的演替以及河流生态健康带来一系列影响 ${ }^{[1-12]}$. 纵观以往研究, 多是简单评价 各区间河段的水体质量 ${ }^{[13-14]}$, 而缺乏对筑坝河段水质大尺度、多断面的时空变化特征研究. 为此, 本文通过 监测 2017 年 12 月- 2018 年 8 月汛期和非汛期的水质数据, 运用主成分分析 (PCA) 和方差分析 (ANOVA) 的方法, 识别水质因子的时空差异性, 探讨导致该区域水质时空分异的原因以及水电梯级开发对河流水质 的影响, 以期为流域综合治理和水库调度提供科学依据.

\section{1 材料与方法}

\section{1 研究区概况}

黑河发源于祁连山北麓, 流域范围介于 $37^{\circ} 45^{\prime} \sim 42^{\circ} 40^{\prime} \mathrm{N}, 96^{\circ} 42^{\prime} \sim 102^{\circ} 04^{\prime} \mathrm{E}$ 之间, 流经青海、甘肃和内蒙 古 3 个省区, 全长 $821 \mathrm{~km}$, 流域总面积 $14.3 \times 10^{4} \mathrm{~km}^{2}$. 黑河以莺落峡和正义峡为界, 划分为上、中、下游, 莺落 峡以上为上游, 主要由两大支流野牛沟河和八宝河及其汇合后形成的部分干流构成, 其干流穿越祁连山谷 后至莺落峡出山流人中游走廊平原, 经正义峡流出, 进人下游额济纳, 最终汇人居延海.

本文选择研究黑河上中游地区, 其中上游海拔在 $2600 \sim 4300 \mathrm{~m}$ 之间, 多年平均气温为 $-5 \sim 4^{\circ} \mathrm{C}$, 年降水 量超过 $350 \mathrm{~mm}$, 部分区域可达 $600 \sim 700 \mathrm{~mm}$, 冰川融水量约为 $4.0 \times 10^{8} \mathrm{~m}^{3}$, 气候阴湿寒冷, 植被覆盖较好, 是 黑河流域的主要产流区. 中游地区年降水量不足 $200 \mathrm{~mm}$, 蒸发量在 $1400 \mathrm{~mm}$ 左右, 区内光热资源充足, 为黑 河径流的主要利用区. 黑河属于典型的内陆河, 径流来源主要有降水形成的地表径流、冰川融冰、融雪和地 下水等,其中降水补给约为 $95 \%$, 冰川融水补给仅为 4\%.6-8 月份是河源径流的丰水期, 该时段径流量约 占全年径流量的 69.6\%, 枯水期 $12-3$ 月份来水量约占全年总量的 $15.9 \%$ 左右 ${ }^{[15-16]}$, 研究区其他水文水力要 素特征见表 1 . 
表 1 黑河上中游河道及水文要素特征 ${ }^{*}$

Tab.1 Channel characteristics and hydrological features of the upper and middle Heihe River

\begin{tabular}{cccccc}
\hline 河段 & 河长 $/ \mathrm{km}$ & 河道比降 $/ \% 0$ & 径流量 $/\left(\times 10^{8} \mathrm{~m}^{3}\right)$ & 降水量 $/ \mathrm{mm}$ & 气温 $/{ }^{\circ} \mathrm{C}$ \\
\hline 野牛沟 & 175 & 8.5 & 7.5 & 424.3 & -1.9 \\
八宝河 & 75 & 9.3 & 14.6 & 422.4 & 2.0 \\
黄藏寺一茑落峡 & 95 & 9.1 & 44.7 & $300 \sim 600$ & $<2.0$ \\
莺落峡一正义峡 & 185 & 2.03 & 10.5 & 140.0 & $2.8 \sim 7.6$ \\
\hline
\end{tabular}

*数据来源于甘肃省水文水资源局 (1968-2013 年).

黑河流域水电梯级开发主要分布在上游干流山区, 其水能资源蕴藏量 $106 \times 10^{4} \mathrm{~kW}$, 可开发量为 $52.8 \times$ $10^{4} \mathrm{~kW}$, 年发电量为 $38.48 \times 10^{8} \mathrm{~kW} \cdot \mathrm{h}$. 根据地形情况, 干流从上到下共规划了 8 座梯级电站, 依次为黄藏寺、 宝瓶河、三道湾、二龙山(松木沟)、大孤山、小孤山(石羊岭)、龙首二级 (西流水)、龙首一级以及龙渠电站; 两支流末端分别建有地盘子和牛板筋电站 (图 1). 总体上该河段是以大孤山、宝瓶河两大电站为主, 地盘 子、牛板筋等小水电站为辅的开发格局. 截止所有样品采集完成时, 干流河段已建成 7 座梯级电站, 支流河 段建成 2 座(表 2).

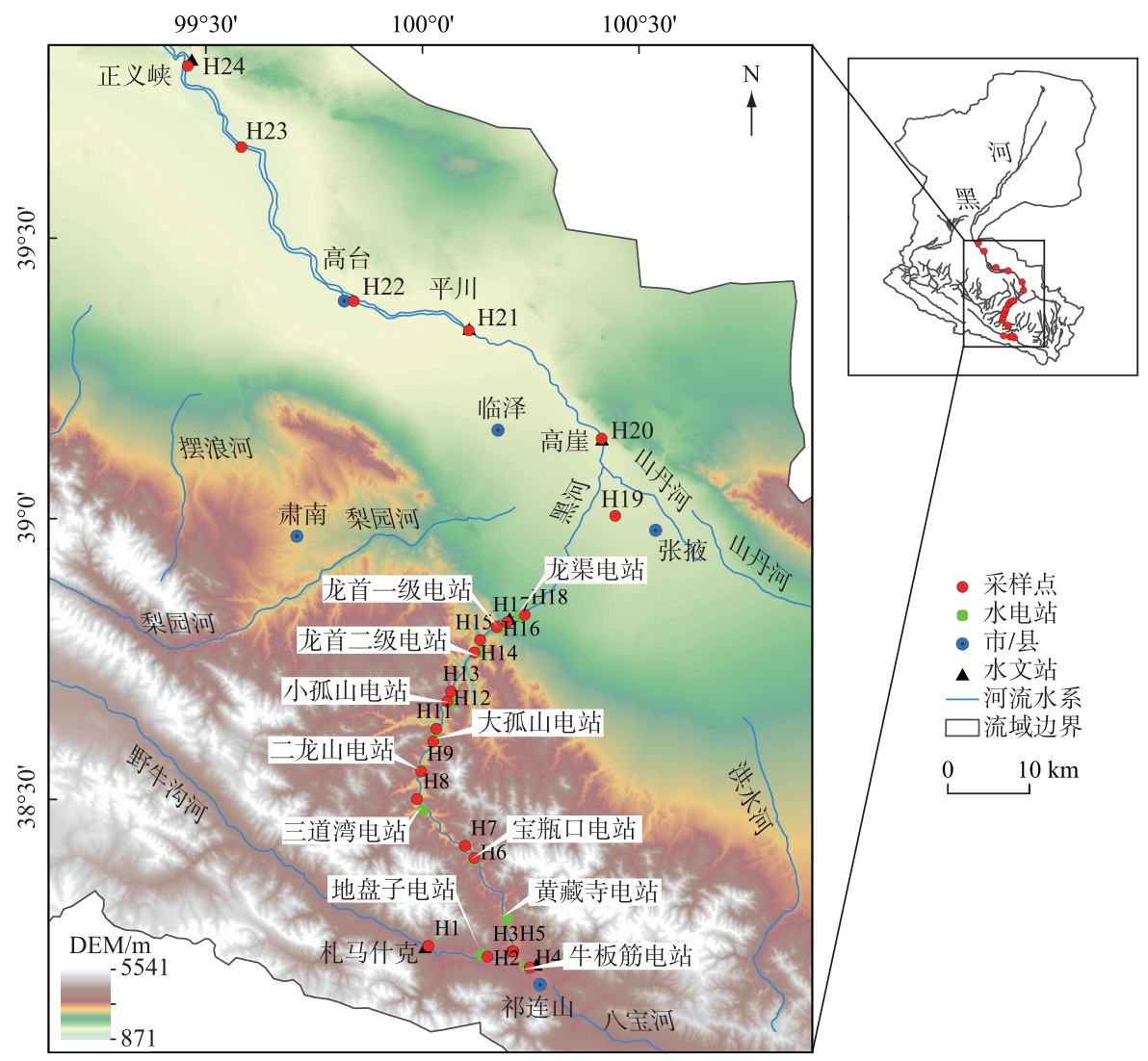

图 1 研究区位置及电站分布

Fig.1 Study area and hydropower stations distribution 
表 2 黑河上游水电开发情况

Tab.2 Hydropower development on the mainstream of the upper Heihe River

\begin{tabular}{ccccc}
\hline 电站名称 & 装机容量 $/\left(\times 10^{4} \mathrm{~kW}\right)$ & 总库容 $/\left(\times 10^{8} \mathrm{~m}^{3}\right)$ & 年平均发电量 $/\left(\times 10^{8} \mathrm{~kW} \cdot \mathrm{h}\right)$ & 机组投产时间 \\
\hline 牛板筋电站 & 1.40 & 0.0021 & 0.07 & 1997 年 7 月 \\
地盘子电站 & 1.60 & 0.0028 & 0.72 & 2004 年 9 月 \\
黄藏寺电站 & 4.90 & 3.67 & 1.43 & 在建 \\
宝瓶河电站 & 12.30 & 2.150 & 4.10 & 2012 年 7 月 \\
三道湾电站 & 11.20 & 0.053 & 4.00 & 2009 年 5 月 \\
二龙山电站 & 5.05 & 0.811 & 1.74 & 2007 年 9 月 \\
大孤山电站 & 6.50 & 1.410 & 2.01 & 2009 年 7 月 \\
小孤山电站 & 10.20 & 0.014 & 3.91 & 2006 年 7月 \\
龙首二级电站 & 15.70 & 0.862 & 5.28 & 2004 年 8 月 \\
龙首一级电站 & 5.20 & 0.132 & 1.98 & 2002 年 4 月 \\
\hline
\end{tabular}

\section{2 样品采集与分析}

水库蓄水运行后, 一方面库区水位雍高, 水深加大, 流速减缓, 加之受水库回水的顶托作用影响, 阻碍了 河流污染物向下流动, 容易使坝上河段出现水体富营养化现象 ${ }^{[17-18]}$; 另一方面, 水库水位的调节以及来流水 体理化性质的差异, 造成水质因子处于频繁的交换状态, 并且这种交换又会反过来进一步改变坝上和坝下 河道水体的物理化学性质 ${ }^{[19]}$. 另外, 通常上游河道水力特性的改变会对下游水环境系统演变带来一系列影 响 ${ }^{[12]}$. 因此, 为探明梯级水电开发对黑河水质变化的影响, 本文在筑坝河流上布设坝上河段、坝下河段和下 游自然河段 3 类采样区域, 选择 24 个主要控制断面进行水样监测 (图 1). 自然河道上根据黑河干流水文站 的分布情况、河流交汇位置及行政区的划分属性, 设置 6 个采样断面 (H19、H20、H21、H22、H23、H24); 坝上 河段依据梯级电站河流人库口位置及库容大小, 设置 9 个采样断面 $(\mathrm{H} 1 、 \mathrm{H} 2 、 \mathrm{H} 5 、 \mathrm{H} 6 、 \mathrm{H} 9 、 \mathrm{H} 10 、 \mathrm{H} 12 、 \mathrm{H} 14$ 、 $\mathrm{H} 16)$; 坝下河段按照梯级水库泄流情况以及电站尾水出口位置, 设置 9 个采样点 ( H3、H4、H7、H8、H11、 H13、H15、H17、H18). 分别于河流非汛期 (2017 年 12 月一翌年 3 月)、汛期 (2018 年 6-8 月) 进行逐月采样, 其中非汛期采样为每月下旬, 汛期为每月上旬, 取样过程按照从上到下的原则分 3 天进行, 每个断面采样 3 次,分别采集 $1000 \mathrm{~mL}$ 水样固定后低温保存运回实验室;另外,各采样时段并没有较大的降水.

监测指标包括水温 $(\mathrm{WT}) 、 \mathrm{pH}$ 值、溶解氧 $(\mathrm{DO})$ 、电导率 $(\mathrm{EC})$ 、五日生化需氧量 $\left(\mathrm{BOD}_{5}\right)$ 、高镇酸盐指数 $\left(\mathrm{COD}_{\mathrm{Mn}}\right)$ 、氨氮 $\left(\mathrm{NH}_{3}-\mathrm{N}\right)$ 、总氮 $(\mathrm{TN})$ 和总磷 $(\mathrm{TP})$, 共计 9 项. 其中 $\mathrm{WT} 、 \mathrm{pH} 、 \mathrm{DO} 、 \mathrm{EC}$ 使用哈希便携式水质仪现 场测定, 剩余指标参照《水和废水监测分析方法》 ${ }^{[20]}$ 中所示方法在实验室测定, 并且每个样品皆平行测定 3 次,计算结果取其平均值.

\section{3 数据分析方法}

本文首先运用主成分分析法 ${ }^{[21]}$ 提取了引起研究区域水质变化的主导因素并加以分析,再结合重复测量 方差分析 ${ }^{[21]}$ 判别黑河坝上河段、坝下河段与自然河段 3 种不同空间类别上的水质指标差异,最后利用单因 素方差分析 ${ }^{[21]}$ 识别不同空间类别上时间尺度的水质变化特征, 从而在时空尺度上探讨梯级水库联合运行对 河流水质的变化规律影响机制. 主成分分析之前, 先对原始数据进行 KMO 和 Barlett 球度检验, 同时为了消 除各指标间不同量纲的影响, 将原数据进行标准化处理 ${ }^{[22]}$, 即均值为 0 , 方差为 1 . 上述所有分析均在 Microsoft Excel 2010、IBM SPSS Statistics 20.0 和 Origin 9.0 软件中实现.

\section{2 结果与分析}

\section{1 水质因子特征与评价}

2017 年 12 月- 2018 年 8 月研究区域水质因子的均值和实测范围见表 3. 由表 3 可知, 监测时段内该区 域水体 $\mathrm{pH}$ 值主要分布在 8.24 8.99 之间, 属于弱碱性水; $\mathrm{DO} 、 \mathrm{BOD}_{5} 、 \mathrm{COD}_{\mathrm{Mn}} 、 \mathrm{NH}_{3}-\mathrm{N} 、 \mathrm{TN}$ 和 TP 浓度均值分别 为 $8.26 、 2.71 、 2.87 、 0.47 、 0.94$ 和 $0.17 \mathrm{mg} / \mathrm{L}$, 根据国家《地表水环境质量标准》(GB 3838-2002) 常规水质项 目评价标准, $\mathrm{TN}$ 和 $\mathrm{TP}$ 属于 III 类水质标准, $\mathrm{BOD}_{5} 、 \mathrm{COD}_{\mathrm{Mn}}$ 和 $\mathrm{NH}_{3}-\mathrm{N}$ 属于 II 类水质标准, $\mathrm{DO}$ 属于 I 类水质标 
准, 基本能满足功能区目标限值. 从实测范围来看, 宝瓶至龙首河段的 TP 浓度、宝瓶水库和大孤山水库的 $\mathrm{BOD}_{5}$ 浓度、平川和高台地区的 $\mathrm{TN}$ 浓度均超出了功能区 III 类水标准限值, 其中 $\mathrm{TN}$ 浓度最大值超出 $\mathrm{V}$ 水标准 的 1.07 倍, $\mathrm{TP}$ 浓度最大值超出湖库 $\mathrm{V}$ 类水标准的 1.44 倍, 说明上述水域污染较重, 甚至部分河段出现了劣 $\mathrm{V}$ 类水现象. 通过 Pearson 相关分析得出 (表 4), EC 与除 $\mathrm{pH} 、 \mathrm{DO} 、 \mathrm{TP}$ 外的其他因子呈极显著正相关, 即 EC 随着 $\mathrm{NH}_{3}-\mathrm{N} 、 \mathrm{TN} 、 \mathrm{BOD}_{5} 、 \mathrm{COD}_{\mathrm{Mn}}$ 浓度的增加而显著增加; $\mathrm{BOD}_{5} 、 \mathrm{COD}_{\mathrm{Mn}} 、 \mathrm{NH}_{3}-\mathrm{N} 、 \mathrm{TP}$ 之间有显著相关性, 表明其 来源具有一致性和相似性; $\mathrm{DO}$ 与 $\mathrm{TP} 、 \mathrm{NH}_{3}-\mathrm{N}$ 呈明显负相关, 说明它们之间是相互影响的; $\mathrm{WT}$ 与 $\mathrm{EC} 、 \mathrm{TN}$ 、 $\mathrm{NH}_{3}-\mathrm{N} 、 \mathrm{BOD}_{5}$ 也表现出较强的相关性, 体现了自然因素水温对河水的影响.

\section{表 3 研究区水质因子特征}

Tab.3 Characteristics of water quality factors in the studied area

\begin{tabular}{ccc}
\hline 水质因子 & 均值 \pm 标准差 & 实测范围 \\
\hline $\mathrm{WT} /{ }^{\circ} \mathrm{C}$ & $13.25 \pm 2.71$ & $2.95 \sim 25.75$ \\
$\mathrm{pH}$ 值 & $8.71 \pm 0.09$ & $8.24 \sim 8.99$ \\
$\mathrm{DO} /(\mathrm{mg} / \mathrm{L})$ & $8.26 \pm 0.41$ & $8.24 \sim 10.34$ \\
$\mathrm{EC} /(\mu \mathrm{S} / \mathrm{cm})$ & $633.26 \pm 85.55$ & $465 \sim 928$ \\
$\mathrm{BOD}_{5} /(\mathrm{mg} / \mathrm{L})$ & $2.71 \pm 0.50$ & $1.24 \sim 4.50$ \\
$\mathrm{COD}_{\mathrm{Mn}} /(\mathrm{mg} / \mathrm{L})$ & $2.87 \pm 0.57$ & $1.31 \sim 5.13$ \\
$\mathrm{NH}_{3}-\mathrm{N} /(\mathrm{mg} / \mathrm{L})$ & $0.47 \pm 0.19$ & $0.12 \sim 1.32$ \\
$\mathrm{TN} /(\mathrm{mg} / \mathrm{L})$ & $0.94 \pm 0.34$ & $0.36 \sim 2.17$ \\
$\mathrm{TP} /(\mathrm{mg} / \mathrm{L})$ & $0.17 \pm 0.06$ & $0.04 \sim 0.36$ \\
\hline
\end{tabular}

表 4 水质因子间的 Pearson 相关系数*

Tab.4 Pearson correlation coefficients of water quality indexes

\begin{tabular}{cccccccccc}
\hline & $\mathrm{WT}$ & $\mathrm{pH}$ & $\mathrm{DO}$ & $\mathrm{EC}$ & $\mathrm{BOD}_{5}$ & $\mathrm{COD}_{\mathrm{Mn}}$ & $\mathrm{NH}_{3}-\mathrm{N}$ & $\mathrm{TN}$ & $\mathrm{TP}$ \\
\hline $\mathrm{WT}$ & 1 & & & & & & & & \\
$\mathrm{pH}$ & -0.19 & 1 & & & & & & & \\
$\mathrm{DO}$ & -0.29 & 0.25 & 1 & & & & & & \\
$\mathrm{EC}$ & $0.71^{* *}$ & 0.16 & -0.07 & 1 & & & & & \\
$\mathrm{BOD}_{5}$ & $0.62^{* *}$ & -0.28 & -0.08 & $0.69^{* *}$ & 1 & & & & \\
$\mathrm{COD}_{\mathrm{Mn}}$ & $0.44^{*}$ & -0.34 & -0.31 & $0.62^{* *}$ & $0.82^{* *}$ & 1 & & & \\
$\mathrm{NH}_{3}-\mathrm{N}$ & $0.51^{*}$ & -0.14 & $-0.45^{*}$ & $0.67^{* *}$ & $0.75^{* *}$ & $0.85^{* *}$ & 1 & & \\
$\mathrm{TN}$ & $0.85^{* *}$ & -0.20 & -0.11 & $0.69^{* *}$ & $0.68^{* *}$ & $0.45^{*}$ & 0.36 & 1 & \\
$\mathrm{TP}$ & 0.40 & -0.15 & $-0.64^{* *}$ & $0.42^{*}$ & $0.43^{*}$ & $0.60^{* *}$ & $0.64^{* *}$ & 0.32 & 1 \\
\hline
\end{tabular}

* 表示在 0.05 水平上 (双侧) 上显著相关; $* *$ 表示在 0.01 水平 (双侧) 上显著相关.

\section{2 水质主成分分析}

经检验得出, 本文用于分析的数据 $\mathrm{KMO}$ 值为 0.67 , Bartlett 球度的显著性满足 $P<0.001$ 的置信度要求, 表明原始数据之间有较强的相关关系, 适合用于主成分分析. 按照特征值 $\lambda>1$ 的原则, 提取了 3 个引起水质 变化的主成分 (表 5), 累积方差贡献率为 $81.949 \%$,能够充分提取原始数据信息.

由表 5 可知,第 1 主成分 PC1 的方差贡献率最大, 为 $53.364 \%$, 与之相关联的参数是 WT、EC、BOD 、 $\mathrm{COD}_{\mathrm{Mn}}$ 和 $\mathrm{TN}$, 体现了气候条件 (WT) 变化对水质的影响, 以及人类活动影响下有机污染物 $\left(\mathrm{BOD}_{5} 、 \mathrm{COD}_{\mathrm{Mn}}\right)$ 和 营养盐( TN) 主导着该区域水质变化; 且 TN 对 PC1 有最强的相关性, 变化特征最明显, 表明其受季节变换、 人类活动等因素影响显著. 第 2 主成分 PC2 的方差贡献率为 $16.671 \%$, 与之相关联的参数是 $\mathrm{NH}_{3}-\mathrm{N} 、 \mathrm{TP}$ 和 $\mathrm{DO}$, 并且 $\mathrm{NH}_{3}-\mathrm{N}$ 与 TP 呈正相关, 与 DO 呈负相关, 同时 Pearson 相关分析也显示它们之间表现出显著负相 关, 说明随着营养盐 $\left(\mathrm{TP} 、 \mathrm{NH}_{3}-\mathrm{N}\right)$ 的输人, $\mathrm{DO}$ 浓度出现相反的变化. 第 3 主成分 PC3 的方差贡献率最低, 为 $11.931 \%$, 与之关联的参数是 $\mathrm{pH}$, 反映了水体的酸碱度, 它对水体的氧化还原反应起着一定的控制作用, 决 
定着河流水体系统的化学稳定性 ${ }^{[23]}$.

表 5 研究区监测指标主成分分析结果 *

Tab.5 Principle component analysis of monitoring index in the studied area

\begin{tabular}{cccc}
\hline 监测指标 & & 主成分 & PC3 \\
\cline { 2 - 4 } & PC1 & PC2 & -0.105 \\
WT & $\mathbf{0 . 8 2 7}$ & 0.172 & $\mathbf{0 . 9 6 5}$ \\
pH & -0.118 & -0.142 & 0.198 \\
DO & 0.071 & $\mathbf{- 0 . 8 3 8}$ & 0.347 \\
$\mathrm{EC}$ & $\mathbf{0 . 8 6 3}$ & 0.223 & -0.149 \\
$\mathrm{BOD}_{5}$ & $\mathbf{0 . 8 5 4}$ & 0.269 & -0.166 \\
$\mathrm{COD}_{\mathrm{Mn}}$ & 0.632 & 0.582 & 0.059 \\
$\mathrm{NH}_{3}-\mathrm{N}$ & 0.574 & 0.708 & -0.149 \\
$\mathrm{TN}$ & $\mathbf{0 . 8 6 6}$ & -0.006 & 0.010 \\
$\mathrm{TP}$ & 0.279 & $\mathbf{0 . 8 4 6}$ & 1.072 \\
$\lambda$ & 4.803 & 1.500 & 11.931 \\
方差贡献率/\% & 53.364 & 16.671 & 81.949 \\
\hline 累积方差贡献率/\% & 53.364 & 70.036 & \\
\hline
\end{tabular}

* 黑体数值为监测指标在不同主成分中因子荷载大于 0.8 的值.

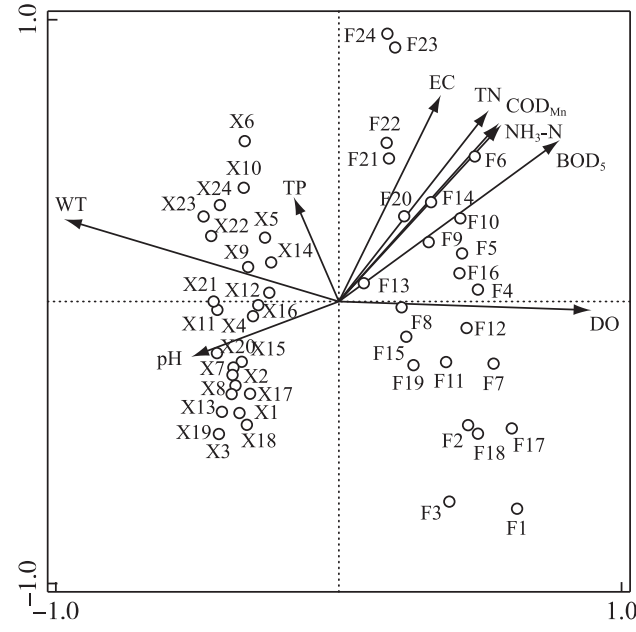

图 2 研究区水质因子 PCA 分析双序图 ( $\mathrm{X}$ 表示汛期样点, $\mathrm{F}$ 表示非汛期样点)

Fig.2 The PCA biplots of water quality factors in the research area

为了更清晰地反映研究区域水质状况, 将各采样点 得分与水质参数荷载矩阵进行 PCA 双序分析 (图 2), 可 以直观反映 3 方面信息: (1)样点在排序空间上呈明显的 季节分布, 逆时针方向来看, 汛期基本聚集在第 2 象限和 第 3 象限, 非汛期在第 1 象限和第 4 象限. (2)水质因子的 箭头越长表示因子荷载越大, 对排序的贡献也越大, 箭 头间的夹角则表示水质因子间的相关性,夹角越小相关 性越高; 图中箭头较长的水质因子在排序空间分成 WT 和 $\mathrm{EC} 、 \mathrm{TN} 、 \mathrm{COD}_{\mathrm{Mn}} 、 \mathrm{NH}_{3}-\mathrm{H} 、 \mathrm{BOD}_{5} 、 \mathrm{DO}$ 两簇排列, 主导着 该区域的水质变化, 且每簇因子间夹角越小, 相关性越 高. $\mathrm{pH}$ 、TP 箭头短, 对排序贡献小, 样品间差异小. (3)将 采样点向水质因子箭头及其延长线作投影, 投影位置在 箭头指向方向越远数值越大, 表明该水质因子对其正贡 献越大, 反之则越小. 逆时针方向来看, $1 、 3$ 象限中, 箭头 指向了排序空间中 $\mathrm{EC} 、 \mathrm{TN} 、 \mathrm{COD}_{\mathrm{Mn}} 、 \mathrm{NH}_{3}-\mathrm{H} 、 \mathrm{BOD}_{5} 、 \mathrm{DO}$ 变 异最大的方向, 反映了非汛期 $\mathrm{BOD}_{5} 、 \mathrm{TN} 、 \mathrm{COD}_{\mathrm{Mn}} 、 \mathrm{NH}_{3}-\mathrm{H}$ 主导着该时段的水质变化,并引起了 $\mathrm{DO}$ 和 $\mathrm{EC}$ 的变化; $2 、 4$ 象限中 $\mathrm{WT}$ 和 $\mathrm{pH}$ 最高, 说明 $\mathrm{WT}$ 和 $\mathrm{pH}$ 主导着汛期 各采样点的水质变化.

\section{3 水质变化的时空分布特征}

2.3.1 水质因子的空间差异性分析 本文将研究区域划分为坝上断面、坝下断面和自然断面 3 组, 对 2017 年 12 月 -2018 年 8 月的水质数据进行重复测量方差分析, 结果表明, WT、EC、BOD $、 \mathrm{COD}_{\mathrm{Mn}} 、 \mathrm{TN}$ 等水质因子在 不同组别上存在显著性差异 $(P<0.05)$.

从它们的空间变化规律可以看出 (图 3), WT、EC、TN 的最大平均值出现在自然断面, 显著高于组间不 存在明显差异的坝上断面和坝下断面. $\mathrm{BOD}_{5}$ 最大平均值出现在坝上断面, 最小平均值出现在坝下断面, 表 现出组间显著性差异. $\mathrm{COD}_{\mathrm{Mn}}$ 最小平均值出现在坝下断面,显著低于不存在显著性差异的坝上断面和自然断 
面. 其中, $\mathrm{TN}$ 和 $\mathrm{EC}$ 浓度值在坝下断面较为均匀集中,而坝上断面的 $\mathrm{COD}_{\mathrm{Mn}}$ 浓度值以及自然断面的 $\mathrm{WT} 、 \mathrm{EC}$ 、 $\mathrm{BOD}_{5}$ 浓度值则相对分散.
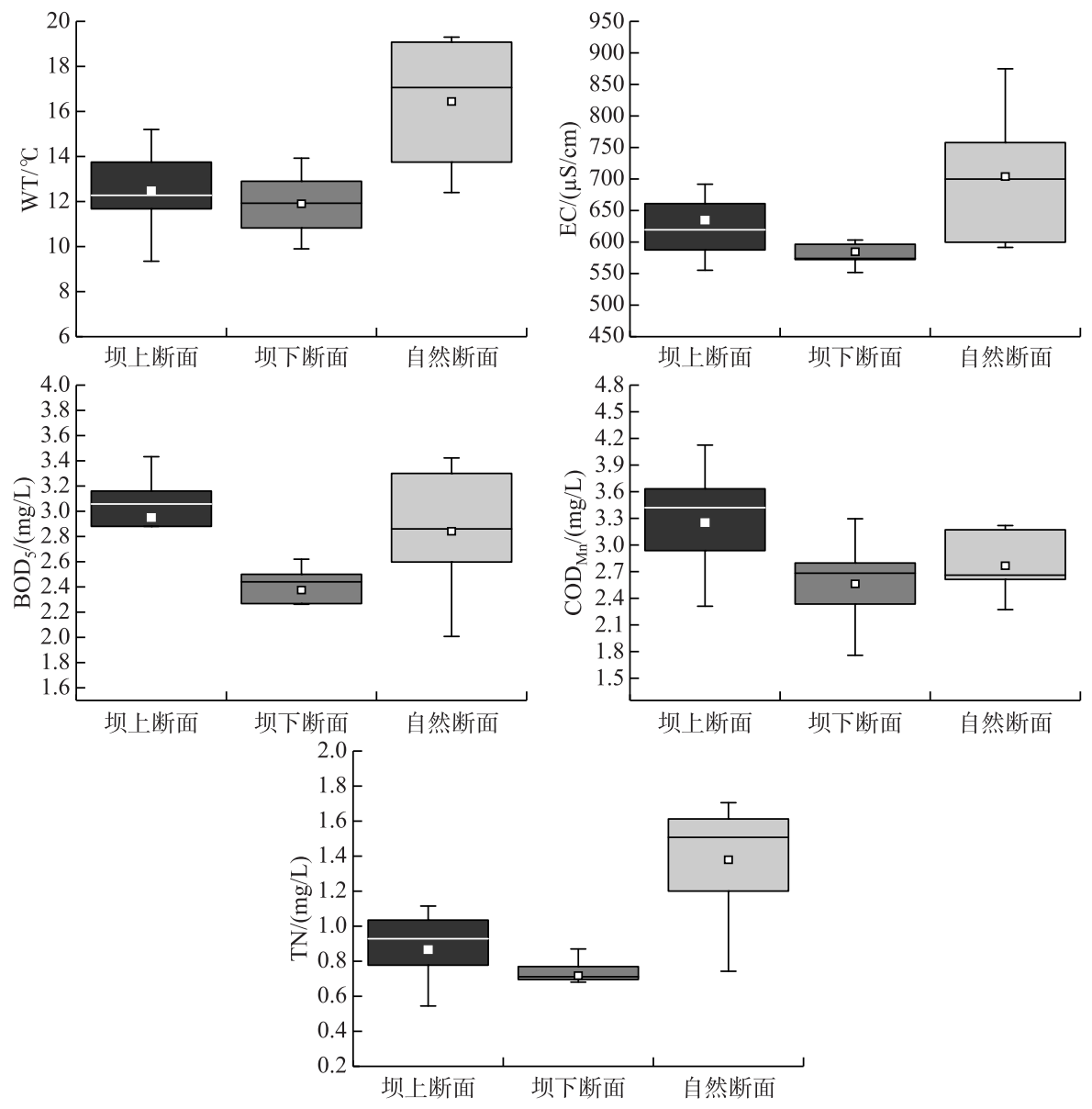

图 3 研究区水质因子的空间差异

Fig.3 Spatial variations of water quality factors in the research area

2.3.2 水质因子的时间差异性分析 由于黑河流域年降雨量的 $70 \%$ 都集中分布在 6-8 月 ${ }^{[24]}$. 据此, 本文将 该区域的 6-8 月划分为汛期, 其余月份 (12 月一翌年 3 月) 归类为非汛期. 水质参数的时间变化采用季节参 数相关矩阵进行评价, 通过单因素方差分析 (One-way ANOVA) 得出, 除 $\mathrm{pH} 、 \mathrm{DO} 、 \mathrm{TP}$ 之外, WT、 $\mathrm{EC} 、 \mathrm{BOD}_{5}$ 、 $\mathrm{COD}_{\mathrm{Mn}} 、 \mathrm{TN}$ 和 $\mathrm{NH}_{3}-\mathrm{N}$ 与季节变化存在显著相关性 $(P<0.05)$. 这些显著性指标中, $\mathrm{TN}$ 具有最大的相关系数 (Spearman's $R=0.701)$, 其次是 $\mathrm{EC}(R=0.700) 、 \mathrm{BOD}_{5}(R=0.692) 、 \mathrm{WT}(R=0.656)$ 和 $\mathrm{NH}_{3}-\mathrm{N}(R=0.552)$. 而与 季节相关的参数可视为引起水质时间变化的主要指标.

在不同空间河段上, 随着季节的变化, $\mathrm{EC} 、 \mathrm{BOD}_{5} 、 \mathrm{COD}_{\mathrm{Mn}} 、 \mathrm{NH}_{3}-\mathrm{N} 、 \mathrm{TN}$ 浓度整体呈上升趋势. 其中 $\mathrm{EC}$ 在各 河段变幅较小; $\mathrm{BOD}_{5}$ 和 $\mathrm{NH}_{3}-\mathrm{N}$ 浓度在各河段的变幅均较大,而坝上河段变幅最大 $; \mathrm{NH}_{3}-\mathrm{N}$ 和 $\mathrm{TN}$ 在自然河段 变幅最大, 坝上河段与坝下河段变幅较小; WT 值无论是在坝上河段,或者是坝下河段, 还是自然河段, 汛期 都要明显高于非汛期, 体现了显著的气候区域差异. 另外, 本文研究发现 DO 浓度并没有呈现出显著的季节 变化, 且 $\mathrm{pH}$ 和 TP 浓度在汛期和非汛期差异也不明显. 总体来看, 研究区各水质因子在非汛期变化较汛期显 著(图4). 

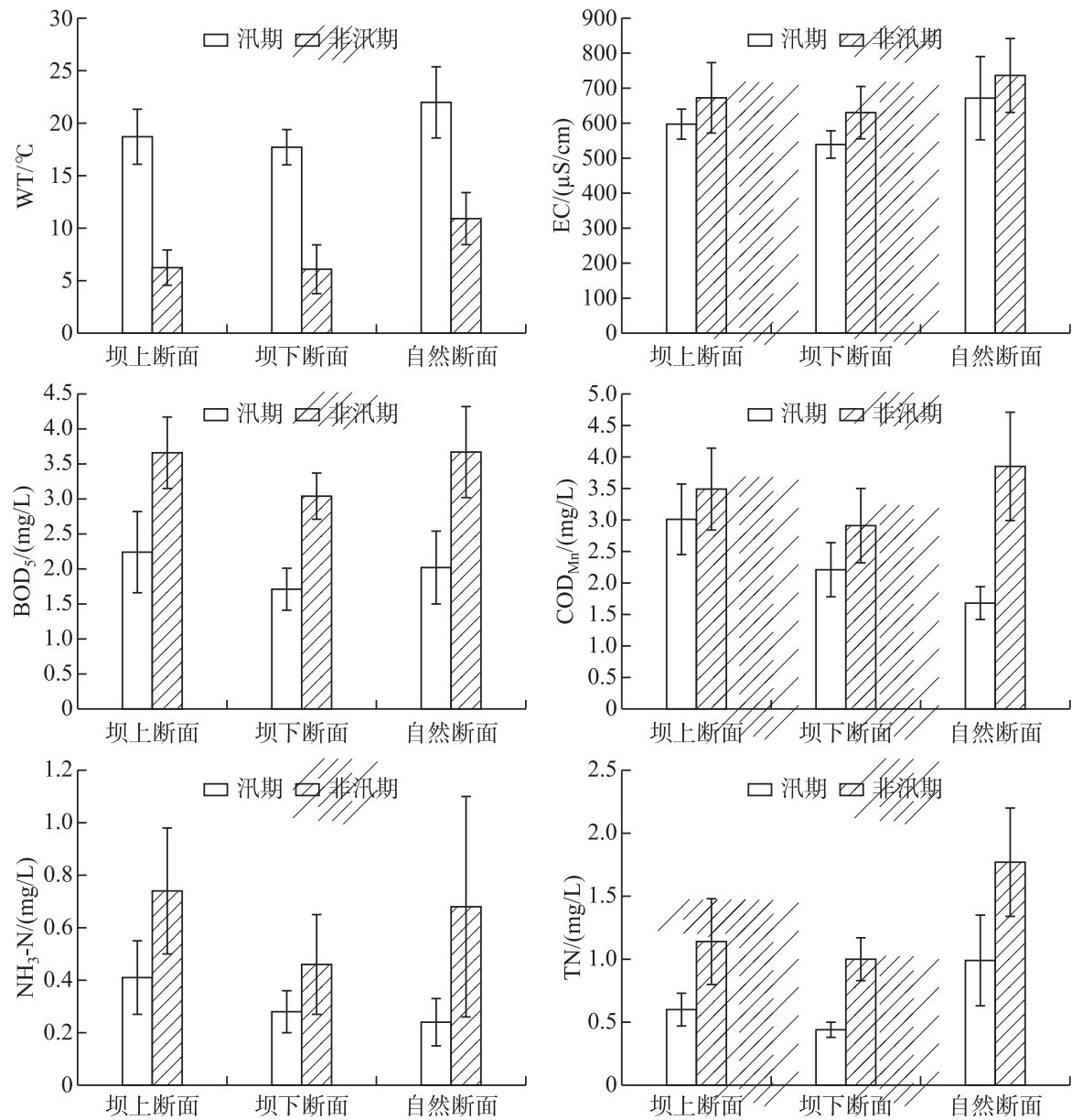

图 4 研究区水质因子的时间差异

Fig.4 Temporal variations of water quality factors in the research area

\section{3 讨论}

\section{1 梯级大坝建设下库区河段水质变化特征分析}

河流筑坝蓄水后, 强水动力条件下的河流搬运作用将逐渐演变为弱水动力条件下的湖泊沉积作用, 进 而增强了水库对河流沉积物、营养盐颗粒等物质的沉积滞留效应, 导致库区水体的物理化学特性发生改 变 ${ }^{[25-26]}$. 有研究表明 ${ }^{[7]}$, 水库库容也可能是其影响因素之一. 据此次调查结果显示, 黑河库区河段上 $\mathrm{NH}_{3}-\mathrm{N}$ 、 $\mathrm{TP} 、 \mathrm{EC} 、 \mathrm{BOD}_{5} 、 \mathrm{COD}_{\mathrm{Mn}}$ 浓度均随库容的增大而升高. 主要原因是水库库容越大, 与之相适应的调节性能越好, 水力停留时间越长, 因而营养盐、有机物等各种污染物的扩散和降解程度也就越缓慢. 通常营养盐、有机物 的滞留会消耗水中大量 $\mathrm{DO}^{[27]}$, 本文中该河段水体 $\mathrm{DO}$ 浓度对 $\mathrm{BOD}_{5} 、 \mathrm{COD}_{\mathrm{Mn}}$ 、TP 浓度的变化也呈现出相似的 响应规律 (图 5), 表明有机物和营养盐浓度是影响库区河段水体 DO 浓度变化的主要因素. 有观点认 为 ${ }^{[28-29]}$, 梯级水库联合运行会将大坝阻隔对河流水环境系统的影响逐级 “放大”, 呈现出迥异于单一水库的 变化特征, 如水温的延迟滞留效应逐渐加大, 各类离子、污染物浓度逐渐升高, 水体富营养化趋势逐渐加重 等. 从本文研究结果来看, 库区河段上 $\mathrm{NH}_{3}-\mathrm{N} 、 \mathrm{TP} 、 \mathrm{BOD}_{5} 、 \mathrm{EC}$ 都随距宝瓶坝前距离的减小而逐渐增大, 且距 坝前距离分别能解释其浓度变化的 $67.7 \% 、 73.6 \% 、 68.9 \%$ 和 77.1\% , 说明上游外源性污染源产生的 $\mathrm{EC} 、 \mathrm{NH}_{3}-\mathrm{N} 、$ $\mathrm{TP} 、 \mathrm{BOD}_{5}$ 浓度在下游筑坝环境下有较明显的沿程累积效应. 但这些污染物浓度却与下游龙首一级水库坝前 

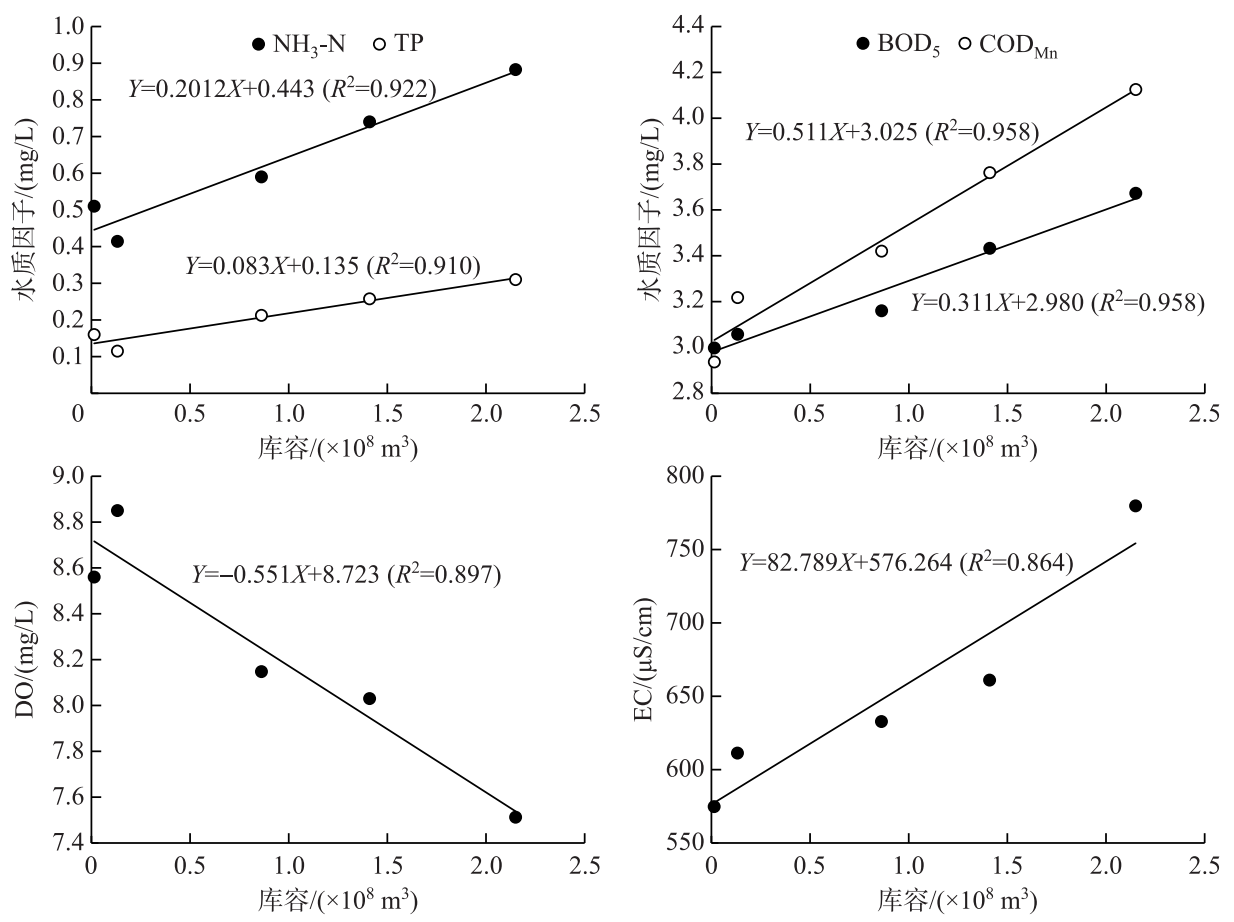

图 5 水质因子与水库库容的关系

Fig.5 The relationship between water quality indexes and reservoir capacity

距离相关性很差(图 6), 只能解释其浓度变化的 $6.9 \% 、 9.0 \% 、 8.4 \%$ 和 $28.0 \%$. 表明河流污染物经梯级水库调 节后 (即沿程累积效应), 各级河段水质污染程度均有所加重, 且其污染程度类似. 黑河梯级水库属于深水峡 谷型水库, 由于年际气温变化较小, 水温分层变化不是特别明显, 没有典型的温跃层, 但正是这种不显著的 温度分层结构, 有效限制了水库上下水团的对流交换, 阻断了下层水体中溶解氧的恢复补充途径 ${ }^{[30]}$, 从而使 水库下层形成了还原性环境, 抑制了亚硝化作用和硝化作用, 导致沉积物中氨化作用形成的 $\mathrm{NH}_{3}-\mathrm{N}$ 不能完 全转化为硝态氮, 进而造成下泄水体的 $\mathrm{NH}_{3}-\mathrm{N}$ 浓度升高, 这是坝上河段和坝下河段 $\mathrm{NH}_{3}-\mathrm{N}$ 浓度没有差异的 重要原因. 筑坝蓄水对河流水温的另一重要影响则是滞温效应,具体表现为下泄水温出现平坦化、均一化特 性 ${ }^{[8]}$. 翟群 ${ }^{[31]}$ 、杨宏 ${ }^{[32]}$ 分析发现黑河高坝水库建成后下泄水温常年维持在较稳定的低温状态, 且秋、冬季有 增温效应, 春、夏季有降温效应, 本文中相应河段水温的时空变化过程也有此类似现象. 总体来看, 黑河梯级 水库建设对河流水质的影响具有三维结构的特征, 即横向、纵向和垂向 3 个方向. 横向上由于库区自身的沉 积作用取代了河流搬运作用, 营养盐、有机物等典型污染物易于发生沉积滞留效应, 加大了库区水体富营养 化的潜在风险, 其程度跟库容大小有一定关系; 纵向上受梯级水库联合运行影响, 大坝阻隔将河流污染物的 累积效应逐级放大,加重了各级库区的污染趋势; 而垂向上水温分层改变了水团混合性质, 干扰了水体中一 些离子的迁移转换过程,并对下泄水体理化特性也产生了一定的影响.

\section{2 不同河段水质变化特征对梯级大坝建设的响应}

从空间尺度上看, 黑河梯级水库蓄水运行以后, 坝上河段、坝下河段及下游自然河段水质的空间差异主 要体现在 WT、EC、BOD $、 \mathrm{COD}_{\mathrm{Mn}}$ 、TN 等指标上. 其中 $\mathrm{BOD}_{5} 、 \mathrm{COD}_{\mathrm{Mn}}$ 浓度在坝上河段最高, 坝下河段最低, 而 $\mathrm{BOD}_{5} 、 \mathrm{COD}_{\mathrm{Mn}}$ 是常被用来反映水体受工农业、生活等有机耗氧类物质污染程度的综合指标. 考虑到上游祁连 地区金属矿采选、冶炼等工矿业活动较强, 因此上游来水中外源性污染源排放的有机物沿河累积于库区, 并 经水库调节后, 上覆水体受污染较重, 下层水体受影响较小, 这虽然在一定程度上降低了下泄水体中污染物 的本底值, 但当遇到大规模降雨或洪水事件, 储存于坝内的有机物被冲刷流出后, 下游水体将受到严重污染. 

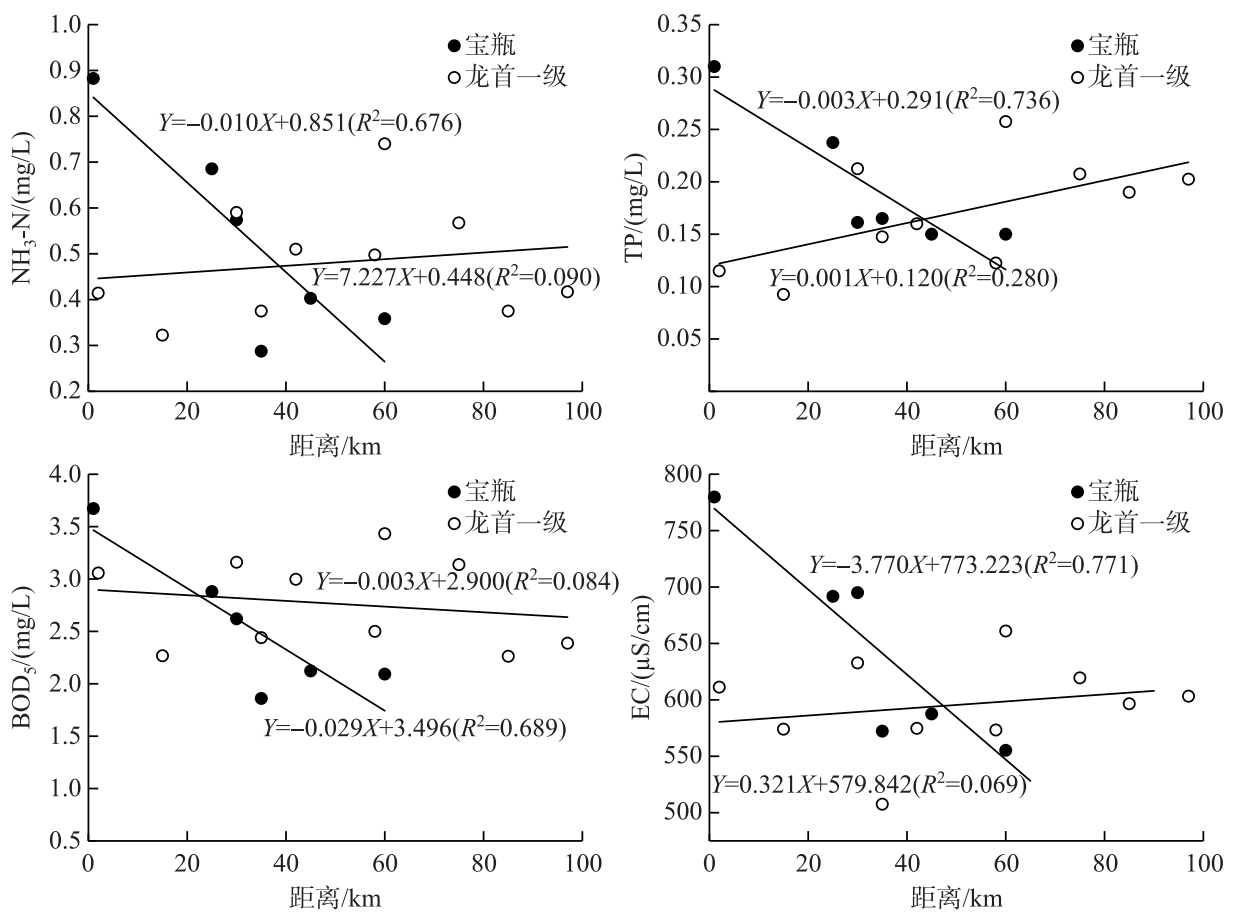

图 6 水质因子与坝前距离的关系

Fig. 6 The relationship between water quality indexes and distance from dam

$\mathrm{TN}$ 浓度在自然河段较高, 主要原因是该河段途径张掖、临泽、高台等市县, 人口稠密, 各地区的工业废水以 及村镇生活污水、农业径流等人类活动向河水排人了大量营养盐, 导致 TN 质量浓度急剧升高, 加之自然河 段河床比降较小, 水流缓慢, 而且受上游筑坝影响, 来流水动力条件减弱, 故污染物质更容易聚集. EC 跟 TN 情况类似,在自然河段最高. Pearson 相关分析显示, 随着水体盐类污染物的增加, EC 也升高. 可能是由于该 地区造纸、农副产品加工企业产生的工业废水以及村镇生活污水等外源性点源污染向河水排放营养盐的同 时,带人了大量溶解性离子, 从而使 $\mathrm{EC}$ 升高 ${ }^{[30]}$, 这也进一步反映了自然河段水质受人类活动 (包括水土流 失) 影响较大. 基于前文分析, 各河段 WT 的变化主要与气候、海拔、人类活动等因素有关. 值得一提的是, 对 于磷元素而言, 水库的拦截效率较高, 可高达 $80 \%$, 是磷元素的一个有效 “汇 ${ }^{[10,33]}$. 有研究表明 ${ }^{[34]}$, 猫跳河 梯级水电开发对 TP 的滞留效果显著,约使磷酸盐浓度降低了 $90 \%$; Seine 河上游水库滞留了 $60 \%$ 的磷元素, 主要是沉降在沉积物中 ${ }^{[31]}$. 本研究中水体 TP 浓度相对较高, 但并没有明显的空间分布差异. 一方面原因是 水库大量拦沙拦磷破坏了水体纳污的缓冲机制, 造成坝下河段的溶解性磷浓度增加 ${ }^{[35]}$; 另一方面, 上游支流 区内强烈的放牧活动产生较多的磷元素, 导致输人河流的 TP 浓度较高, 而中游自然河段周围是农灌区, 区 内农业非点源污染、化肥和农药的使用以及雨水冲刷携带的颗粒磷使水体 TP 浓度增加. 同时值得注意的 是, 宝瓶水库 TP 浓度远高于其他水库, 主要原因是宝瓶电站位于黑河梯级水库的最上游, 直接来源于上游 支流区内的大量磷元素, 被沉积滞留于库区底泥后, 无论是在厌氧或好氧环境下, 磷元素的释放都随温度的 升高而增长 ${ }^{[36]}$.

时间尺度上,由于黑河梯级水库以季节性调度方式为主,故季节变化可能对水质变化影响更大. 单因素 方差分析表明,不同河段绝大多数水质因子随时间变化呈现出季节变化的特征,如非汛期 $\mathrm{EC} 、 \mathrm{BOD}_{5}$ 、 $\mathrm{COD}_{\mathrm{Mn}} 、 \mathrm{NH}_{3}-\mathrm{N} 、 \mathrm{TN}$ 浓度显著高于汛期,这也与 $\mathrm{PCA}$ 双序分析结果基本一致. 不同季节水质变化主要受降水、 温度、水文条件、水库运用方式等因素影响 ${ }^{[37]}$. 其中非汛期 (12-3 月) 是黑河径流最小的季节, 水库水量补 给和换水频度减弱, 水力停留时间延长, $\mathrm{EC} 、 \mathrm{BOD}_{5} 、 \mathrm{COD}_{\mathrm{Mn}} 、 \mathrm{NH}_{3}-\mathrm{N}$ 等典型污染物容易滞留; 加之非汛期 (冬 
季)气温较低, 微生物活动减弱, 水体自净能力低下, 最终导致该时段河流污染负荷较高. 而与此相反的是, 汛期 (6-8 月) 上游来水充足, 水库弃水较多, 污染物一起被排往下游的也多; 另外, 汛期降水的增加对污染 物产生了较强的稀释净化作用, 同时水温增加, 流域及河道内微生物活动增强, 能够迅速降低水体中污染物 的浓度,因此汛期河流污染程度相对较轻.

纵向来看, 杜有军等 ${ }^{[38]}$ 的研究表明 2001-2008 年黑河自然河段水质有逐年加重的趋势, 具体表现为 $\mathrm{COD}_{\mathrm{Mn}} 、 \mathrm{NH}_{3}-\mathrm{N}$ 浓度总体上升, 其浓度年均值分别为 5.04 和 $0.80 \mathrm{mg} / \mathrm{L}$; 而 2017-2018 年监测结果为 2.77 和 $0.46 \mathrm{mg} / \mathrm{L}$, 呈现下降趋势, 这从侧面反映出近年来流域范围内对企业废水、生活污水等点源污染的治理有一 定效果, 但本次监测数据也表明 $\mathrm{TN}$ 浓度有所上升, 分析认为是自然河段水质仍受农业面源污染影响. 杨永 宇等 ${ }^{[13]}$ 和李慧 ${ }^{[39]}$ 研究指出 2007-2011 年黑河筑坝河段 (札马什克至莺落峡河段) $\mathrm{COD}_{\mathrm{Mn}}$ 浓度变化不明显, $\mathrm{TP} 、 \mathrm{NH}_{3}-\mathrm{N}$ 浓度略有下降. 但从 2017-2018 年监测结果来看, $\mathrm{COD}_{\mathrm{Mn}} 、 \mathrm{TP} 、 \mathrm{NH}_{3}-\mathrm{N}$ 浓度均有上升趋势, 说明随 着蓄水进程的推进,水质变化特征也发生了相应改变.

\section{4 结论}

1) 根据国家《地表水环境质量标准》(GB 3828-2002) 常规水质项目评价标准, 黑河上中游全年水质类 别基本能满足功能区目标限值, 但 TP 浓度及 $\mathrm{TN}$ 浓度在局部地区出现了超标现象. 主成分分析表明该区域 水质时空变化的主要影响因素为 $\mathrm{WT} 、 \mathrm{pH} 、 \mathrm{DO} 、 \mathrm{EC} 、 \mathrm{TN} 、 \mathrm{TP}$ 和 $\mathrm{BOD}_{5}$.

2 ) 水质因子在时空分布上有一定的差异性. 空间尺度上, WT、EC、BOD $、 \mathrm{COD}_{\mathrm{Mn}} 、 \mathrm{TN}$ 等指标具有显著性 差异, 其中坝上河段受 $\mathrm{BOD}_{5} 、 \mathrm{COD}_{\mathrm{Mn}}$ 影响较大, 自然河段 $\mathrm{WT} 、 \mathrm{EC}$ 和 $\mathrm{TN}$ 为关键指标, 而各因子对坝下河段水 质影响较小. 时间尺度上, $\mathrm{WT} 、 \mathrm{EC} 、 \mathrm{BOD}_{5} 、 \mathrm{NH}_{3}-\mathrm{N}$ 与季节变化存在明显相关性, 是不同河段水质时间变化的 控制因子,且大多数水质因子在非汛期变化最明显.

3 ) 水质因子的空间差异主要受祁连、张掖地区外源性污染物排放以及筑坝环境下水动力条件改变而产 生的沉积滞留效应和沿程累积效应的影响; 时间差异主要受降水、温度、水文条件等季节性影响因素和梯级 水库联合运用模式的影响.

4) 研究表明,外源性污染源依然是导致水质变差的主要因素,梯级筑坝是导致水质变差的间接因素. 因 此控制该区域人类活动所造成的外源性污染源, 并针对不同种类污染物的季节变化特征实施合理的水库运 行方式是改善水电梯级开发水域水质状况的关键.

\section{5 参考文献}

[ 1 ] Li K, Li ZH, Chen HB et al. Spatial variations of the water quality in Jianhe River of Wudang Mountain in the upper reaches of Danjiangkou Reservoir. J Lake Sci, 2013, 25(5) : 649-654. DOI: 10.18307/2013.0505. [李昆, 李兆华, 陈红 兵等. 丹江口水库上游武当山剑河水质空间差异性分析. 湖泊科学, 2013, 25(5): 649-654.]

[ 2 ] Mao ZP, Wang YC, Peng WQ et al. Advances in effects of dams on river ecosystem. Advances in Water Science, 2005,16 (1) : 134-140. [毛战坡, 王雨春, 彭文启等. 筑坝对河流生态系统影响研究进展. 水科学进展, 2005, 16(1): 134-140.]

[ 3 ] Yang K, Deng X, Li XL et al. Impacts of hydroelectric cascade exploitation on river ecosystem and landscape: a review. Chinese Journal of Applied Ecology, 2011, 22 (5): 1359-1367. [杨昆, 邓熙, 李学灵等. 梯级开发对河流生态系统和 景观影响研究进展. 应用生态学报, 2011, 22(5): 1359-1367.]

[ 4 ] Wang Y, Lian YT, Feng Q et al. Effects of dam interception on the spatial distribution of sediment granularities in Heihe River. J Lake Sci, 2019, 31(5) : 1459-1467. DOI: 10.18307/2019.0505. [王昱, 连运涛, 冯起等. 筑坝拦截对黑河 河道沉积物粒度空间分布的影响. 湖泊科学, 2019, 31(5) : 1459-1467.]

[ 5 ] Dynesius M, Nilsson C. Fragmentation and flow regulation of river systems in the Northern third of the world. Science, 1994, 266 (5186) : 753-762.

[ 6 ] Petts G ed. Impounded rivers: perspectives for ecological management. New York: Wiley, Chichebster, 1984: 67-71.

[ 7 ] Liu CQ, Wang, FS, Wang CY et al. Responses of aquatic environment to river damming-from the geochem ical view. Resources and Environment in the Yangtze Basin, 2009, 18(4): 384-396. [刘丛强, 汪福顺, 王雨春等. 河流筑坝拦截的 
水环境响应——来自地球化学的视角. 长江流域资源与环境, 2009, 18(4) : 384-396. ]

[ 8 ] Ji DB, Long LH, Xu Het al. Advances in study on cumulative effects of construction of cascaded reservoirs on water environment. Advances in Science and Technology of Water Resources, 2017, 37(3): 7-14. [纪道斌, 龙良红, 徐慧等. 梯级 水库建设对水环境的累积影响研究进展. 水利水电科技进展, 2017, 37(3): 7-14.]

[ 9 ] Ma ZL, Cheng GW. Progress in research on impacts of river hydro-power engineering on eco-environment. Advances in Water Science, 2006, 17(5) : 748-753. [麻泽龙, 程根伟. 河流梯级开发对生态环境影响的研究进展. 水科学进展, $2006,17(5): 748-753$.

[10] Jossette G, Leporcq B, Sanchez N et al. Biogeochemical mass-balances ( C, N, P, Si) in three large reservoirs of the Seine Basin( France). Biogeochemistry, 1999, 47(2) : 119-146.

[11] Wang Y, Lu SG, Feng Q et al. Spatio-temporal characteristics and source identification of water pollutants in the upper and middle reachers of Heihe River. China Environmental Science, 2019, 39(10): 4194-4204. [王昱, 卢世国, 冯起等. 黑 河上中游水质时空分异特征及污染源解析. 中国环境科学, 2019, 39(10) : 4194-4204.]

[12] Li Z, Chen YB, Li C et al. Advances of eco-environmental effects and adaptive management in river cascading development. Advances in Earth Science, 2018, 33(7): 675-686. [李哲, 陈永柏, 李狆等. 河流梯级开发生态环境效应与适 应性管理进展. 地球科学进展, 2018, 33(7): 675-686.]

[13] Yang YY, Yin L, Liu C et al. Water quality assessment of Heihe River Basin based on grey correlation method and BP neural network. Yellow River, 2017, 39(6) : 58-62. [杨永宇, 尹亮, 刘畅等. 基于灰关联和 BP 神经网络法评价黑河 流域水质. 人民黄河, $2017,39(6): 58-62$.

[14] Li H, Zhou YC. Water quality evaluation of Heihe River Basin based on fuzzy matter-element model. Yellow River, 2015, 37(10)：78-80, 85. [李慧, 周轶成. 基于模糊物元模型的黑河流域水质评价. 人民黄河, 2015, 37 (10): 78$80,85$.

[15] Guo QL, Yang YS, Chang XS et al. Annual variation of Heihe River runoff during 1957-2008. Progress in Geography, 2011, 30(5): 550-556. [ 郭巧玲, 杨云松, 畅祥生等. 1957-2008 年黑河流域径流年内分配变化. 地理科学进展, $2011,30(5): 550-556$.

[16] Yu ZS, Bai F, Li WP. Characteristic and cause analysis of water resources evolution in the middle reaches of the Black River Basin. China Rural Water and Hydropower, 2007, (6) : 1-3, 7. [余志山, 白福, 李文鹏. 黑河流域中游地区水 资源演变特征及成因分析. 中国农村水利水电, 2007, (6) : 1-3, 7.]

[17] Cheng B, Wang X, Ma JC et al. Spatial Distribution characteristics of nutrients and chlorophyll-a in the Lancang River Basin under cascade Reservoirs. Environmental Science, 2019, 40(4) : 1779-1787. [程豹, 望雪, 马金川等. 澜沧江流域 梯级水库建设下水体营养盐和叶绿素 a 的空间分布特征. 环境科学, 2019, 40(4) : 1779-1787.]

[18] Ran GH, Ge JW, Miao WJ et al. Spatial-temporal differentiation of water quality in Gufu River of Three Gorges Reservoir. Acta Ecologica Science, 2013, 33(17) : 5385-5396. [舟桂花, 葛继稳, 苗文杰等. 三峡库区古夫河水质时空分异特 征. 生态学报, 2013, 33(17) : 5385-5396.]

[19] Ji DB, Liu DF, Yang ZJ et al. Hydrodynamic characteristics of Xiangxi Bay in Three Gorges Reservoir. Science China Press, 2010, 40 (1): 101-112. [ 纪道斌, 刘德富, 杨正健等. 三峡水库香溪河库湾水动力特性分析. 中国科学: 物 理学 力学 天文学, 2010, 40(1): 101-112.]

[20] Editorial Board of "Monitoring and analysis methods of water and wastewater", Ministry of Environmental Protection of the People's Republic of China ed. Monitoring and analysis methods of water and wastewater: fourth edition. Beijing: China Environmental Science Press, 2002. [国家环境保护总局《水和废水监测分析方法》编委会. 水和废水监测分析方 法: 第 4 版. 北京: 中国环境科学出版社, 2002.]

[21] Li YG, Du HW, Huang YS et al eds. SPSS 19.0 introduction and improvement of statistical analysis. Beijng: Tsing hua University Press, 2014: 308. [李玉光, 杜宏巍, 黄永生等. SPSS19. 0 统计分析人门与提高. 北京: 清华大学出版社, 2014: 308.]

[22] Sun GY, Liu X, Li LH. Spatial distributions of water physicochemical properties in the Kaidu River. Arid Zone Research, 2017, 34(2) : 259-265. [孙桂燕, 刘翔, 李兰海. 开都河水理化性质的空间分布特征. 干旱区研究, 2017, 34(2): 259-265.]

[23] Ma XX, Wang LC, Liao LL. Spatio-temporal characteristics and source identification of water pollutants in Wenruitang River Watershed. Environmental Science, 2015, 36(1): 64-71. [马小雪, 王腊春, 廖玲玲. 温瑞塘河流域水体污染时 
空分异特征及污染源识别. 环境科学, 2015, 36(1) : 64-71.]

[24] Liu SY, Zhang GH, Zhang CY et al. Water resources system evolution and impact of human activities in Heihe River Basin. Journal of Jilin University: Earth Science Edition, 2008, 38(5): 806-812, 819. [刘少玉, 张光辉, 张翠云等. 黑 河流域水资源系统演变和人类活动影响. 吉林大学学报: 地球科学版, 2008, 38(5): 806-812, 819.]

[25] Hart DD, Poff NL. A special section on dam removal and river restoration. BioScience, 2009, 52(8) : 653-655.

[26] Li GR, Liu CQ, Chen C et al. Dissolve inorganic carbon and its carbon isotope composition in cascade reservoir of the Maotiao River during summer and autumn. Environmental Science, 2009, 30(10) : 2891-2897. [李干蓉, 刘丛强, 陈椽 等. 猫跳河流域梯级水库夏-秋季节溶解无机碳 (DIC) 含量及其同位素组成的分布特征. 环境科学, 2009,30 (10) : 2891-2897.]

[27] Yang FX, Jian HM, Tian L et al. Distribution characteristics of COD and DO and its influencing factors in the daliaohe estuary. Environmental Science, 2014, 35(10): 3748-3754. [ 杨福霞, 简慧敏, 田琳等. 大辽河口 COD 与 DO 的分布特 征及其影响因素. 环境科学, 2014, 35(10): 3748-3754.

[28] Stanford JA, Ward JV. Revisiting the serial discontinuity concept. River Research \& Applications, 2001, 17 (4) : 303-310.

[29] Zhang SJ, Yan JP, Li GQ. Cumulative effects of cascade development project adjustment on water temperature. Journal of Hydraulic Engineering, 2014, 45(11): 1336-1343[张士杰, 间俊平, 李国强. 流域梯级开发方案调整的水温累积影 响研究. 水利学报, 2014, 45(11): 1336-1343.]

[30] Wang CY, Zhu J, Ma M et al. Thermal stratification and paroxysmal deterioration of water quality in a canyon reservoir, Southwestern China. J Lake Sci, 2005, 17 (1) : 54-60. DOI: 10.18307/2005.0109. [王雨春, 朱俊, 马梅等. 西南峡谷 型水库的季节性分层与水质的突发性恶化. 湖泊科学, 2005, 17(1) : 54-60.]

[31] Qu Q. Research on the river hydropower engineering PEIA - in the case of Heihe River (Huangzangsi reach to Yingluoxia) hydropower engineering PEIA [Dissertation]. Lanzhou: Lanzhou University, 2007. [篗群. 流域水电规划环境影响评价 研究一一黑河干流 (黄藏寺 莺落峡河段) 水电梯级开发规划环境影响评价为例 [学位论文]. 兰州: 兰州大 学, 2007.]

[32] Yang H. Study on cumulative effects assessment of cascade hydropower development in drainage area [Dissertation]. Lanzhou: Lanzhou Uinverity, 2007. [杨宏. 流域水电梯级开发累积环境影响评价研究 [学位论文]. 兰州: 兰州大 学, 2007.]

[33] Ran XB, Yu ZG, Yao QZ et al. Advances in nutrient retention of dams on river. J Lake Sci, 2009, 21(5) : 614-622. DOI : 10.18307/2009.0502. [ 手祥滨, 于志刚, 姚庆祯等. 水库对河流营养盐滞留效应研究进展. 湖泊科学, 2009, 21(5) : 614-622. ]

[34] Li YQ, Lu CX, Deng O et al. Regional response of ecological effects of cascade reservoirs development within the Maotiaohe River Watershed. Resources Science, 2011, 33(8) : 1454-1461. [李亦秋, 鲁春霞, 邓欧等. 猫跳河流域梯级开发的 生态效应区域响应. 资源科学, 2011, 33(8) : 1454-1461.]

[35] Zhou JJ, Zhang M, Li Z. Dams altered Yangtze River phosphorus and restoration countermeasures. J Lake Sci, 2018, 30 (4) : 865-880. DOI: 10.18307/2018.0401. [周建军, 张曼, 李哲. 长江上游水库改变干流磷通量、效应与修复对策. 湖泊科学, 2018, 30(4) : 865-880.]

[36] Guo PC, Wang PF, Jia SB. Research progress of the environmental impact factors of internal phosphorus loading release in river system. Journal of Nanjing Forestry University: Natural Science Edition, 2008, 32(3) : 117-121. [ 郭鹏程, 王沛芳, 贾锁宝. 河流内源磷释放环境影响因子研究进展. 南京林业大学学报：自然科学版, 2008, 32(3) : 117-121.]

[37] Zhang XY, Ma PM, Gao QH et al. Spatial-temporal variations of water quality in upstream and downstream of Three Gorges Dam. J Lake Sci, 2019, 31(3) : 633-645. DOI: 10.18307/2019.0303. [张馨月, 马沛明, 高千红等. 三峡大坝上下游 水质时空变化特征. 湖泊科学, 2019, 31(3) : 633-645.]

[38] Du YJ. Analysis of water pollution change and water quality evaluation in the middle reaches of Heihe River. Gansu Water Conservancy and Hydropower Technology, 2009, 45(1) : 35-37. [杜有军. 黑河干流中游段水污染变化分析与水质评 价. 甘肃水利水电技术, $2009, \mathbf{4 5}(1): 35-37$. $]$

[39] Li H. Water quality assessment and trend analysis in the Heihe River Basin [Dissertation]. Lanzhou: Lanzhou Uinverity of Technology, 2014. [李慧. 黑河流域水质评价及变化趋势分析 [学位论文]. 兰州: 兰州理工大学, 2014.] 